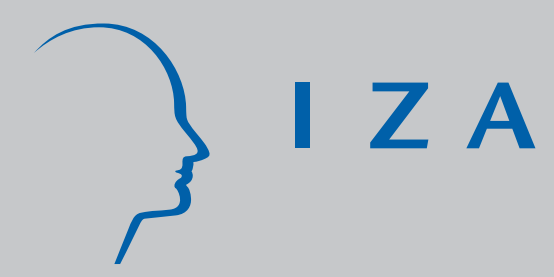

IZA DP No. 2017

Reasons for Wage Rigidity in Germany

Wolfgang Franz

Friedhelm Pfeiffer

March 2006 


\title{
Reasons for Wage Rigidity in Germany
}

\author{
Wolfgang Franz \\ ZEW and University of Mannheim \\ Friedhelm Pfeiffer \\ ZEW, University of Mannheim \\ and IZA Bonn
}

\section{Discussion Paper No. 2017 \\ March 2006}

\author{
IZA \\ P.O. Box 7240 \\ 53072 Bonn \\ Germany \\ Phone: +49-228-3894-0 \\ Fax: +49-228-3894-180 \\ Email: iza@iza.org
}

Any opinions expressed here are those of the author(s) and not those of the institute. Research disseminated by IZA may include views on policy, but the institute itself takes no institutional policy positions.

The Institute for the Study of Labor (IZA) in Bonn is a local and virtual international research center and a place of communication between science, politics and business. IZA is an independent nonprofit company supported by Deutsche Post World Net. The center is associated with the University of Bonn and offers a stimulating research environment through its research networks, research support, and visitors and doctoral programs. IZA engages in (i) original and internationally competitive research in all fields of labor economics, (ii) development of policy concepts, and (iii) dissemination of research results and concepts to the interested public.

IZA Discussion Papers often represent preliminary work and are circulated to encourage discussion. Citation of such a paper should account for its provisional character. A revised version may be available directly from the author. 
IZA Discussion Paper No. 2017

March 2006

\section{ABSTRACT}

\section{Reasons for Wage Rigidity in Germany*}

This study investigates institutional and economic reasons for downward wage rigidity regarding three occupational skill groups. Based on a survey of 801 firms in Germany and an econometric analysis, we find strong support for explanations based on the effects of labour union contracts and efficiency wages that differ between skill groups. Survey respondents indicate that labour union contracts and implicit contracts are important reasons for wage rigidity for the (less) skilled. Specific human capital and negative signals for new hires are causes of the stickiness of wages for the highly skilled. Compared with US evidence, German firms seem to attach more importance to labour union contracts and specific human capital.

JEL Classification: J41, J51, K31

Keywords: wage rigidity, labour union contracts, efficiency wage theory, implicit contract theory, regulation of labour

Corresponding author:

Friedhelm Pfeiffer

Centre for European Economic Research (ZEW)

P.O. Box 103443

D-68034 Mannheim

Germany

Email: pfeiffer@zew.de

\footnotetext{
* The authors gratefully acknowledge financial support from the German Science Foundation (Deutsche Forschungsgemeinschaft) under grants FR 715/3-1,2 and PF 331/3-1. We would like to thank Bernhard Boockmann, Bernd Fitzenberger, Norbert Janz, Joachim Möller, Walter Oechsler, and Volker Rieble for many competent remarks. The usual disclaimer applies.
} 


\section{Introduction}

Despite high unemployment rates and strong competition for jobs among the unemployed, firms in Germany as well as in other industrialized countries rarely tend to cut wages. In recessions, hour's reductions and workers' displacements seem to be more common than wage reductions. As a result, labour markets appear to be rather imperfect. Given the costs of the resulting unemployment, the question arises why societies treat themselves to the luxury of wage rigidity. ${ }^{1}$ Hence, as pointed out e.g. by Howitt (2002), explanations for wage stickiness are central to the great macroeconomic debates. As a prerequisite for constructing macroeconomic models, an understanding of the forces which prevent labour markets from clearing is essential.

Several studies aim to shed light on the relevance of institutional and theoretical explanations for wage rigidity in firms. For recent comprehensive discussions see Bewley (1999), Malcomson (1999) and Howitt (2002). A special branch of these studies contributes to the literature by asking firms why they behave the way they do (see table I). ${ }^{2}$ They indicate that economic theory provides well-founded explanations for wage rigidity, among them are efficiency wage theories, contract theory, implicit contract theory and fairness theory. Note, however, that sample sizes in most of these surveys are small and firms are not always selected randomly. Furthermore, information concerning the type of labour contracts is rare and the methodology used differs between the studies which makes comparisons of the results difficult if not impossible.

\footnotetext{
${ }^{1}$ See e.g. Bertola (1999) who compares employment, unemployment and wage dynamics in a number of industrialized countries, including Germany and the United States. On the aggregate level, real wages in Germany have increased considerably in the last forty years, while employment growth was only moderate. The United States has experienced a significant rise in employment, accompanied by a moderate rise in real wages.

${ }^{2}$ Evidence on the existence of wage rigidity based on pay histories of individual workers is provided, among others, by Altonji and Devereux (2000) and Card and Hyslop (1997) for the United States, Beissinger and Knoppik (2003), Pfeiffer (2003) for Germany, and Fehr and Götte (2005) for Switzerland.
} 
Kaufman (1984) interviewed 26 small firms in Britain, Blinder and Choi (1990) 19 large firms in New Jersey and Eastern Pennsylvania. Campbell and Kamlani (1997) focus on five prominent explanations of wage rigidity (contract theory, implicit contract theory, efficiency wage theories, fair wage theory and insider-outsider theory) and introduced three skill categories of labour. Their study is based on a survey of 184 mainly large US firms. Agell and Lundborg (1995 and 2003) surveyed 159 relatively large unionized firms from the Swedish manufacturing sector in 1991 and again in 1998. In a further study, Agell and Bennmarker (2002) interviewed 885 representatively selected Swedish firms in 1999. Bewley (1995, 1998, and 1999) interviewed 335 business and union leaders, counsellors of unemployed persons and business consultants in the Northeast of the United States.

Our study, which is the first survey of firms on wage rigidity for Germany, comes closest to the methodology employed by Campbell and Kamlani (1997). We extend their work in different directions. Although the design of our questionnaire deliberately contains the questions, among others, raised by these authors in order to allow a direct comparison, we additionally collect detailed information on the legal type of collective wage agreements and labour contracts of the firms as control variables. Moreover, our findings are based on econometric methods and a larger and randomly selected sample of firms. In our study, the influence of firm-specific factors and labour contracts on the assessment of different explanations of wage rigidity is tested by using ordered probit models (rather than simply by bivariate t-tests as in other studies). Finally, we analyse the statistical correlation between different explanations for wage rigidity. This aspect is important, too, for the following reasons. For example, efficiency wage theories and contract theory may by themselves in principle provide a rationale on their own for not cutting wages. But if firms see labour union contracts as an important reason for wage rigidity, efficiency wages may lose part of their explanatory power or, alternatively, they may strengthen each other. 
Firms in Germany and other countries under consideration operate in roughly comparable economic environments. While the economic rationale for wage rigidity may be independent of national legislation, the relevance of each of these explanations may differ. Since German workers enjoy a higher degree of employment protection than e.g. workers in the United States do, and codetermination and collective bargaining is more common in Germany, their bargaining power is supposed to be higher, especially in collective wage bargaining rounds. Differences in legislation may also indirectly influence the relevance of efficiency wage explanations for wage rigidity, because more strict employment protection legislation or a wider application of collective wage agreements might impose more restrictions on firms' wage policies.

The paper is organized as follows. Section II describes our and some peculiarities of the structure of wage contracts in the responding firms. Section III discusses firm responses with respect to distinct explanations of wage rigidity and compares the results with those found for the United States, among others. Section IV highlights the firms' support for each of the statements on wage rigidity. Section $\mathrm{V}$ investigates the issue of pay differentiation in labour union contracts. Section VI concludes.

\section{Overview of the Survey and the Structure of Wage Contracts in Germany}

Between February and April 2000, 801 firms responded to a standardized written questionnaire which was sent to the head of the human resources department of 5,158 firms. These firms were selected randomly (after stratification) from about 160,000 firms (each with more than nine employees) operating in the following industries: chemical industry; metal industry, electrical goods industry and machinery; wholesale and retail trade; finance and insurance; firm related services and other sectors. Details of the sample design are relegated to the appendix. 
Table II contains descriptive statistics about the sample population and the respective population of all firms. The survey had a response rate of roughly 16 percent, as well as a high item response rate. Descriptive statistics about the characteristics of all firms have been calculated under the assumption of a random response. It turns out that respondents support for the reasons for wage rigidity do not differ substantially between the sample population and the respective population of all firms.

To begin with, 38 percent of the firms apply labour union contracts. These firms employ 70 percent of sample employees indicating that collective wage agreements rise with firm size, which confirms the findings of Kohaut and Schnabel (2003) based on the "IABBetriebspanel” survey. Each of these firms has either industry or firm level bargaining, i.e. they are members of the bargaining employers' association or bargain individually with a union, or, to a lesser extent, they apply labour union contracts on a voluntary basis, in order to avoid costs associated with wage bargaining, for example. Although these numbers document the role of collective wage bargaining in Germany, readers should keep in mind that 62 percent of the firms, employing 30 percent of the workers, do not participate in this system. Furthermore, in roughly 50 percent of the firms with collective wage agreements effective wages are significantly higher than wages collectively bargained, see e.g. Franz (2003). The presence of collective wage agreements therefore does not necessarily indicate that wage determination at the firm level is absent. In 83 percent of the responding firms wages are bargained individually between employers and workers, either as an alternative or in addition to labour union contracts. Both industry level and individual wage bargaining can be frequently observed in the same firm.

Taken together, there is a stronger emphasis on industry level wage bargaining in Germany than compared e.g. with the United States. Although firms with industry level bargaining are not forced legally to pay their non-union workforce wages as high as negotiated, as a rule, firms do so for obvious reasons (e.g. otherwise the employees would join the union). Around 
80 percent of the firms with labour union contracts responded that their pay schemes do not differ between union and non-union workers (see table II). ${ }^{3}$ These figures differ remarkably from those in other countries. ${ }^{4}$

The causes of wage rigidity may be subject to firm heterogeneity, as has been emphasized by Bewley (1999). Hence, the survey tries to capture essential parts of this heterogeneity. The reasons for wage rigidity might differ between firms with and without labour union contracts, as well as with respect to industry affiliation, firm size, skill level of the workforce, regional location of the (headquarter of the) firm and whether firms have difficulties recruiting new staff, pointing to the labour market situation as an influence on firms’ responses.

Three broad skill categories are distinguished - highly skilled, skilled and less skilled. Less skilled are defined as workers without a formal occupational degree, skilled are workers who have been certified by the German Dual Vocational Training System and highly skilled are workers who have received a degree from a (technical) university. Our definitions of skill groups differ from the ones used by Campbell and Kamlani (1997) in order to account for the German educational and vocational system. In contrast to the United States the majority of blue-collar workers in Germany has been educated in the German Dual Vocational Training System, and should be categorized as being skilled. Hence, in the German survey the share of skilled workers with a more specific vocational training is higher than in the United States. The industrial composition between both countries is similar with respect to manufacturing and trade. In the German survey, however, there are more firms belonging to the firm-related service sector and fewer firms belonging to finance, insurance, and construction.

\footnotetext{
${ }^{3}$ From a legal point of view, firms with labour union contracts have to apply them only to members of the bargaining union. Only 30 percent of the workforce population in Germany are a member of a union (Franz, 2003, p. 242).

${ }^{4}$ According to Campbell and Kamlani (1997, Footnote 1), 12.3 percent of workers in the United States are represented by labour unions. In their sample, 14.7 percent of the firms are unionized. Although union membership declined in Germany (see Franz, 2003, p. 242 ff.) as well as in the United States and Great Britain (see Acemoglu et al., 2001), the application of labour union contracts in Germany is rather stable. For example:
} 


\section{Explanations for Wage Rigidity}

\subsection{Introduction}

Firms were given nine statements based on various theories of wage rigidity. ${ }^{5}$ The introductory statement was: "Even in economically bad times or in times of high unemployment, firms seldom reduce workers' pay, although that may help them survive and save working places. Please assess the following explanations as 'not important', 'of minor importance', 'moderately important' or 'very important'.” Respondents were asked to assess the statements for each of the three worker categories separately.

Table III reports the frequency distribution of the responses for the nine statements, two values for the average scores - one for the sake of comparison the sample and one for the population of firms - and the average scores from Campbell and Kamlani (1997, see table IV). The number of observations with valid information per skill group and explanation varies between 744 and 792. The responses to statement $a$ (labour union contracts) are reported separately for the groups of firms with labour union contracts. In order to allow for comparison, the four responses were converted into numerical scores: 1 (not important), 2 (of minor importance), 3 (moderately important), and 4 (very important). An average score over 2.5 is seen as strong support and an average over 3.0 as very strong support (see Blinder and Choi, 1990). In addition, table III reports the whole frequency distribution of results.

For example, statement a (emphasizing labour union contracts as a reason for wage rigidity) received the highest score for less skilled workers. Nevertheless, for some 19 percent of the surveyed firms applying labour union contracts, negotiated wages were unimportant or of minor importance to the explanation of wage rigidity. The significance of firm characteristics is tested with multivariate ordered probit models. Summary results are reported

in the finance and insurance industries, only 14 percent of workers are unionized; however, 70 percent of the firms apply labour union contracts to almost all relevant workers. 
in table $\mathrm{V}$. This methodology may document the relevance of firm characteristics more appropriately than bivariate t-tests of scores as found in the study of Campbell and Kamlani (1997), given the numerical conversions of qualitative statements and a possible presence of multicollinearity. The number of observations with valid information per skill group and explanation in these estimations vary between 689 and 726. The following discussion focuses on the German study and differences with results obtained for the United States.

\subsection{Discussion}

In Germany, as well as in the United States, some reasons for wage rigidity differ between skill groups, others do not. The exchange of pay and labour seems to be far away from the textbook model of one homogenous labour market. Human capital, labour regulation and heterogeneity influence the wage distribution and wage rigidity.

In Germany, statements $a$ (labour union contracts) and $b$ (implicit contracts) received (very) strong support for less and medium skilled workers. For 57 percent of respondent's labour union contracts are very important reasons for wage rigidity for the less skilled. A high degree of employment protection, codetermination in firms and collective bargaining is quite common in Germany which strengthens the bargaining power in collective wage bargaining rounds. This is in line with Swedish evidence (Agell and Lundborg, 1995 and 2003) and points to the role of collective wage bargaining legislation and the relatively high degree of labour regulation in Germany (see Botero et al., 2004).

For highly skilled workers, statements $c$ (negative signals), $e$ (fluctuation costs) and $h$ (specific human capital) received very strong support. There is also strong support for statements $e$ (fluctuation costs) and $h$ (specific human capital) for skilled workers. Fluctuation costs therefore provide an important explanation for wage rigidity for skilled labour. In large German industrial firms, the costs of training in specific human capital, for example, can

\footnotetext{
${ }^{5}$ The questionnaire is available on request.
} 
represent up to a one year salary (Franz and Soskice, 1995). There is more support for the explanation of wage rigidity based on specific human capital in Germany compared to the United States which points to the higher relevance of specific human capital in the German economy (see Krueger and Kumar, 2004).

Statement $d$ emphasizes the effect of wages on effort. In Germany, this statement receives strong support for all skill groups, while the values of the scores are rather similar. Campbell and Kamlani (1997) found a slightly higher support for less-skilled and blue-collar workers. The responses to statements $b$ on implicit contracts and $e$ on the relevance of fluctuation costs are very similar in both surveys. Implicit contracts, wage related effort variation and fluctuation costs therefore seem to be lasting reasons for wage rigidity, despite different degrees of centralization in wage determination in both countries.

Major differences concern the effect of wages on quits and new hires. In the United States, statement $g$ (adverse selection model applied to quits) received the strongest support for all skill groups. Responses did not differ much between skill groups in the German survey, although average scores are lower. One possible explanation for these differences may be due to employment protection legislation. According to German laws, employers must take social aspects into account when dismissing employees. Therefore, it might be more difficult to dismiss the least productive workers. Firms in the United States can put less emphasis on social aspects.

Further differences seem to exist in the responses to statement $i$ (workers' resentments). A possible explanation for the stronger support for statement $i$ in Germany rests on codetermination and collective wage bargaining legislation in Germany. Because of these specific workers’ rights, the motive for conflict avoidance may be more relevant in Germany. This finding does not contradict the assumption of profit maximizing behaviour, but indicates more severe constraints, resulting from labour regulation, on firm behaviour in Germany. 
There is also a difference related to statement $c$ that emphasises the effect of wages on new hires, which finds much stronger support in Germany. One possible explanation is that in Germany, information on wages and the wage structure is more transparent and readily available due to the broader application of labour union contracts. Therefore, German firms might be somewhat more concerned with negative signalling effects stemming from wage cuts, which undermine their attractiveness to skilled workers. Presumably this is reinforced by a compressed wage structure in Germany (see Blau and Kahn, 1999, and Fitzenberger, 1999).

The stronger support for statement $f$ (harassment) may confirm the view that the insideroutsider theory provides a foundation for collective rather than for individual behaviour (Fehr, 1990). Campbell and Kamlani (1997) also find a much stronger support for statement $f$ (harassment) in unionised firms. To shed some more light on the relevance of insideroutsider-mechanism in Germany, we asked respondents in our German survey whether workers would agree upon "pay moderation" either "for keeping their own job" or "for creating additional working places”. Respondents were given three categories of responses: yes, no, and not known for certain. Table IV reports the results. While, in the opinion of respondents, a majority of workers would comply with lower pay in order to secure their jobs, very few workers would comply in order to create additional employment. However, there is no evidence how workers themselves would view this issue.

To test the relevance of firm characteristics for the responses, ordered probit models for each statement were estimated. Table $\mathrm{V}$ reports whether a variable has proved to be significantly different from zero at the five percent level in the ordered probit model. ${ }^{6}$ In the case of a significant coefficient, table V reports “+” for positive values, and “-“ for negative values.

\footnotetext{
${ }^{6}$ In addition to the firm characteristics reported in table $\mathrm{V}$, we tested the influence of the skill structure, profit expectations in 2000 compared to 1998/1999 and the share of flexible pay components. However, we could not find any evidence of the relevance of these variables.
} 
Firm characteristics play a significant role in respondents’ support for some but not all statements on wage rigidity, as indicated also by Campbell and Kamlani (1997) and Agell and Lundborg (1995 and 2003). Firms joining the bargaining employers’ association significantly more often expressed support for statement $a$, which emphasizes the relevance of labour union contracts for wage rigidity. There is no difference between firms which voluntarily apply these contracts and those which do not at all apply (the reference category). This indicates that the type of labour union contract matters for the explanations of wage rigidity. For firms voluntarily applying collective wage agreements (around 20 percent of all firms applying collective wage agreements, see table II) these contracts are not specific for the explanation of wage rigidity, which seems plausible. So even in the group of firms joining the collective wage system economic reasons for wage rigidity are important.

Turning to the relevance of efficiency wage considerations, there is twofold evidence. Firstly, the application of labour union contracts negatively affects the support for statements c (negative signals for hires; for (less) skilled workers) if the firm joins the employer association. Secondly, support for statement $d$ (effort variation; for (less) skilled workers) and $e$ (turnover cost; for highly skilled workers) is obtained only if the firm bargains with the union. These findings seem to indicate that firms who participate in the system of collective wage bargaining as members of the employers' association or with firm specific contracts have less fear that wage reductions enhance the difficulty of hiring, raise fluctuation costs, or reduce effort. Since lowering wages in labour union contracts would apply to all firms, its specific impact on an individual firm is not that important, therefore.

Those firms who report strong evidence for recruitment difficulties for skilled staff support efficiency wage models with a higher probability, thereby reducing the room for wage cuts for the workers employed. However, this is not true for firms who report recruitment difficulties for highly skilled staff. From our point of view this surprising result may mirror higher 
mobility cost for skilled labour compared with highly skilled labour in the German labour market.

There are only a few significant industry, firm size and regional effects. Smaller firms seem to have more fear that wage reduction induces higher turnover (statement $e$ ) for (highly) skilled and a higher loss of specific human capital for all skill groups (statement $g$ ). However, smaller firms have less fear that lower wages reduces effort (statement $d$ ) for highly skilled. Otherwise there are no clear firm size effects. In addition, the location of the firms' headquarter seems to have only minor impacts for explanations of wage rigidity.

The presence of workers' councils reduce the support for explanations emphasizing the effect of wages on new hires (statement $c$ ), on effort (statement $d$ ) and of specific human capital (statement $g$ ), mainly for (less) skilled workers. Workers’ councils in Germany as a rule represent the group of (less) skilled workers and therefore it is not surprising that their impact on explanations for highly skilled labour is small.

In summing up, the following explanations for wage rigidity put forward by economic theory are approved by survey respondents: In both countries, firms see implicit contracts as a potential reason for wage rigidity for less skilled workers, as well as turnover costs and a negative influence of wage reduction on workers’ effort for all skill groups. Major differences between firms in Germany and the United States concern insider-outsider behaviour, labour union contracts, and explanations based on specific human capital and adverse selection considerations.

\section{The Relationship between Different Statements}

While each of the theories may, in principle, provide a reasonable explanation for wage rigidity, different explanations might be complements or substitutes in practice. Wage rigidity resulting from labour union contracts may be observed even in the absence of such contracts because of the existence of (unobservable) implicit contracts. Various efficiency wage 
arguments may as a whole provide greater explanatory power than one specific efficiency wage theory alone, compared with insider-outsider considerations, for example. If respondents support two statements, a positive relationship between these responses would indicate (according to our interpretation) that the additional or incremental influence or explanatory power of one of the two statements may, in fact, be small (depending on the magnitude of the correlation). Otherwise, if there is no observable relationship between two statements, each of the two theories behind the statements has its own power in explaining wage rigidity. Finally, a negative relationship indicates that more support for one statement reduces the support for the other, hence, the two theories may not be relevant at the same time.

While Campbell and Kamlani (1997) asked firms to indicate the most important statement for explaining wage rigidity, our correlation analysis provides an attempt to study the relationship between different explanations. Respondents were asked about their view on nine statements for three worker groups. Taken together, one obtains 351 possible bivariate relations, which are quantified with Goodman's and Kruskal's $\gamma$. This measure of correlation takes account of the ordered nature of the responses. It varies between minus and plus one. For example, a value of 0.7 implies that from 100 firms which express full support for a specific statement, 70 firms do so for another statement, too. For practical purposes and space restrictions, table VI reports 27 correlation values between the worker categories for each statement and 108 correlation values between the statements for each worker group. ${ }^{7}$

The following findings deserve attention. Firstly, there is a skill specific pattern with respect to the reasons for wage rigidity (part 1 of table VI). The reasons for wage rigidity are very similar between skilled and highly skilled labour for all nine statements, and fairly 
similar for medium and less skilled labour. While the correlation between less and highly skilled labour is also significant, the numerical values, with the only exceptions of statement $f$ (harassment) and $i$ (workers’ resentments) are lower.

The following discussion concerns part 2, table VI. The five statements emphasizing different versions of efficiency wages (statements $c, d, e, g$, and $h$ ) are positively correlated for all worker categories, with relatively high numerical values. These findings suggest that the incremental contribution of an additional version of efficiency wages for the explanation of wage rigidity seems to be rather small, although these five statements together receive a very strong support.

Thirdly, there is a positive correlation between labour union contracts (a) and implicit contract $(b)$ explanations for wage rigidity for all skill groups. This finding suggests that workers' desire for stable wages is met in part by labour union contracts. Fourthly, there is mixed evidence on the correlation between labour union contracts and statements based on efficiency wages $(c, d, e, g$, and $h$ ). This suggests that labour union contracts as well as efficiency wages provide a rationale for wage rigidity on its own. Labour union contracts seem to be no substitute for efficiency wages. The same seems to hold for the relationship between implicit contracts and efficiency wages. Although there are some positive values of a correlation between efficiency wage and implicit contract explanations, the numerical values are rather small. Hence, while each of these three groups of theoretical explanations contributes to the understanding of wage rigidity, the incremental explanatory power of implicit and labour union contracts seems to be lower when both are relevant.

Fifthly, insider-outsider theory $(f)$ and conflict avoidance $(i)$ as possible explanations of wage rigidity are weakly positively correlated with each other and with the efficiency wage

\footnotetext{
${ }^{7}$ The other values deal with the correlation between a statement for skill group A and another statement for skill group B. It is well-known that labour demand between skill groups is not independent from each other, see Hamermesh (1993). Despite its importance for policy reasons, we are, however, not aware of any study that links
} 
explanations. Therefore, the additional explanatory power of these two theories, given the efficiency explanations, is moderately lower compared with its average and unconditional explanatory power as measured by the average score. To some extent, these findings may confirm the relevance of fluctuation costs, specific human capital and wage related effort variation for the bargaining power of insiders and the conflict avoidance strategy of firms.

\section{Pay Differentials in Labour Union Contracts}

From a legal point of view firms in Germany are free to join the collective wage bargaining system. According to survey respondents, labour union contracts are an important rationale for wage rigidity in Germany. Therefore the future of the German system of collective wage bargaining will depend on firms choices. We asked firms which apply such contracts whether they are planning to escape from industry level wage bargaining. 85 percent of survey respondents denied. From the remaining firms, 39 percent planned to withdraw membership of the employers' association, 24 percent aimed at outsourcing parts of the production and 25 wanted to bargain directly with the union. From these answers, it seems reasonable to conclude that there is some limited pressure on labour union contracts, possibly caused by the wage rigidity induced by negotiated wages.

This pressure may be the reason for the observed trend on negotiating more flexible pay structures in the annual bargaining rounds in recent years. Labour union contracts nowadays more often contain hardship clauses and the possibility for lower pay for new hires and the long-term unemployed. Whether there exist such possibilities for pay differentiation in labour union contracts and, if so, to what extent these firms take advantage of this flexibility is reported in table VII. It contains the questions and the distribution of answers of respondents on hardship clauses, reduced pay for new hires, and reduced pay for long-term unemployed. 
Only 11 to 15 percent of the respondents confirm the existence of these flexible pay structures in labour union contracts, which is not that much. Surprisingly, however, the majority of firms which can take advantage of pay differentiation do not make use of it. There are two possible explanations for that finding. Firstly, at the time the survey was conducted (1999), Germany was not in an economy wide recession, hence there was presumably no urgent need for applying the hardship clause. Secondly, differentiated pay with respect to new hires and long-term unemployed may be considered as being unfair by employees (see Campbell and Kamlani, 1997, Bewley, 1999, Agell and Lundborg, 2003).

As a result of our survey, the overwhelming share of firms which did not take advantage of differentiated pay answered that there was no economic necessity to do so, and only a minority feared disadvantages when operating on the labour market (multiple answers were possible). This result holds for hardship clauses as well as for differentiated pay for new hires and/or for the long-term unemployed. Since the number of respondents for these questions is rather small, the results should be taken with some caution. However, they are in line with the adverse selection model as applied to new hires and the relevance of fairness considerations in pay determination.

\section{Conclusions}

This study contributes to the literature concerning the empirical relevance of prominent explanations for wage rigidity, such as contract theory, implicit contract theory, efficiency wage theories, fair wage theory, and insider-outsider theory. Based on a survey of 801 firms in Germany, our findings rest on a unique set of questions on the type of labour union contracts in German firms and on econometric methods. Among others, the statistical correlation between various explanations for wage rigidity is analysed, because, say, two different explanations may by themselves provide a rationale for not cutting wages on their own, but lose part of their explanatory power when both are relevant. 
Furthermore, we compare explanations for wage rigidity between Germany and the United States, two countries with diverse labour market legislations. Since German workers enjoy a higher degree of employment protection than American workers do and codetermination and collective bargaining is quite common in Germany, their bargaining power might be higher, especially in collective wage bargaining rounds. Differences in legislation may also indirectly influence the relevance of efficiency wage explanations for wage rigidity, because a more strict employment protection legislation or a wider application of labour union contracts might impose more restrictions on firms’ wage policies.

German firms strongly support labour union contracts as an explanation for wage rigidity for (less) skilled workers. Specific human capital and negative signals for new hires received strong support for highly skilled employees. Campbell and Kamlani (1997) found the strongest support in the United States for the adverse selection model as applied to quits of highly skilled white-collar workers. This is not the case in our study, which seems to be the consequence of stronger employment protection legislation in Germany. In both countries, firms support implicit contract theory as an explanation for wage rigidity for less skilled workers as well as turnover costs and a negative influence of wage reduction on workers' effort for all skill groups. Compared with the evidence in the United States, insider-outsider behaviour and labour union contracts are more relevant for the explanation of wage rigidity from the viewpoint of German firms, which is probably due to the higher degree of unionization in Germany compared with the United States.

Different causes of wage rigidity are related to each other. There is a positive correlation between labour union contracts and implicit contract explanations for wage rigidity for all skill groups. This finding suggests that workers' desire for stable wages is met in part by labour union contracts. There is also a relatively high correlation between five variants of efficiency wage theories. This finding suggests that the incremental contribution of an additional version of efficiency wages for explaining wage rigidity is rather small, although 
each of the five variants receives high average scores. Finally, labour union contracts and efficiency wage explanations provide a rationale for wage rigidity on its own. Labour union contracts are no substitute for efficiency wage explanations of wage rigidity, and efficiency wage explanations provide no substitute for implicit contracts.

The German experience seems to more similar to the Swedish one, where unionisation is higher than in Germany. Despite the influence of labour market institutions and labour legislation on wage rigidity, however, the economic rationale concerning wage rigidity has its own weight.

\section{Data Appendix}

The present study uses a large firm address data base at the Centre for European Economic Research (ZEW), Mannheim Germany. The data base is an original data set established by a German credit rating association (Verband der Vereine Creditreform (VVC)), which has been widely used by economists (see e.g. Harhoff, Stahl and Woywode, 1998). This data set contains information on firm size and industry. In the industries selected for the purpose of the current study, the data base contains the addresses of 160,607 firms with more than nine employees in December 1999. The industries chosen represent manufacturing and service industries and firms from the sector of firm related services. From these addresses 5,100 were selected randomly on the basis of a two way stratification scheme by five industries and six firm size categories.

Larger firms and firms in chemistry and finance and insurance were over sampled to get a reasonable number of responses in these cells. Table VIII documents the number of randomly selected firms in each industry and firm size cell, their share in the population and the number of respondents. Under the assumption of random response, weight factors had been calculated for inferences about the original firm population. 


\section{References}

Acemoglu, D., Aghion, P. and G.L. Violante (2001) "Deunionization, Technical Change and Inequality”, Carnegie Rochester Conference Series on Public Policy: Bi-Annual Conference Proceedings 55: 229-264.

Agell, J. and H. Bennmarker (2002) "Wage Policy and Endogenous Wage Rigidity: A Representative View from the Inside”, CESifo Working Paper 751, Munich.

Agell, J. and P. Lundborg (1995) "Theories of Pay and Unemployment: Survey Evidence from Swedish Manufacturing Firms”, Scandinavian Journal of Economics XCVII: 295-307.

(2003) "Survey Evidence on Wage Rigidity and Unemployment: Sweden in the 1990s", Scandinavian Journal of Economics 105 (1): 15-30.

Altonji, J.G. and P.J. Devereux (2000) "The Extent and Consequences of Downward Nominal Wage Rigidity”, Research in Labor Economics 19: 383-431.

Bertola, G. (1999) “Microeconomic Perspectives on Aggregate Labor Markets”, in: Ashenfelter, O. and D. Card, eds., Handbook of Labor Economics, Vol. 3C, Amsterdam: Elsevier, 29823024.

Bewley, T.F. (1995) “Depressed Labor Markets as Explained by Participants”, The American Economic Review LXXXV: 250-254.

— (1998) “Why Not Cut Pay?” European Economic Review 42: 459-490.

— (1999) “Why Wages Don’t Fall During a Recession”, Cambridge, Mass.: Harvard University Press.

Blau, F.D. and L.M. Kahn (1999) "Institutions and Laws in the Labor Market”, in: Ashenfelter, O. and D. Card, eds., Handbook of Labor Economics, Vol. 3C, Amsterdam: Elsevier, 1399-1461.

Blinder, A.S. and D.H. Choi (1990) "A Shred of Evidence on Theories of Wage Stickiness", The Quarterly Journal of Economics 105: 1003-1015.

Botero, J., S. Djankov, R. La Porta, F. Lopez-de-Silanes and A. Shliefer (2004) "The Regulation of Labor”, The Quarterly Journal of Economics 4: 1339-1382.

Campbell, C.M. and K.S. Kamlani (1997) “The Reasons for Wage Rigidity: Evidence from a Survey of Firms”, The Quarterly Journal of Economics 3: 759-789.

Card, D. and D. Hyslop (1997) “Does Inflation “Grease the Wheels of the Labor Market”? in: Romer, C.D. and D.H. Romer, eds., Reducing Inflation: Motivation and Strategy, Chicago: The University of Chicago Press, 71-114.

Fehr, E. (1990) “Cooperation, Harassment, and Involuntary Unemployment: Comment”, The American Economic Review 80: 624-630.

Fehr, E. and L. Götte (2005) "Robustness and Real Consequences of Nominal Wage Rigidity", Journal of Monetary Economics (forthcoming).

Fitzenberger, B. (1999) Wages and Employment Across Skill Groups: An Analysis for West Germany, Heidelberg: Physica.

Franz, W. (2003) Arbeitsmarktökonomik, 5. ed., Berlin: Springer. 
Franz, W. and D. Soskice (1995) “The German Apprenticeship System”, in: Buttler, F., W. Franz and R. Schettkat, eds., Institutional Frameworks and Labor Market Performance: Comparative Views on the US and German Economies, London: Routledge, 208-234.

Hamermesh, D.S. (1993) Labor Demand, Princeton, NJ: Princeton University Press.

Harhoff, D., K. Stahl and M. Woywode (1998) "Legal Form, Growth and Exit of West German Firms: Empirical Results for Manufacturing, Construction, Trade and Service Industries”, The Journal of Industrial Economics XLVI: 453-488.

Howitt, P. (2002) "Looking Inside the Labor Market: A Review Article”, Journal of Economic Literature XL: 125-138.

Kaufman, R.T. (1984) “On Wage Stickiness in Britain’s Competitive Sector”, British Journal of Industrial Relations XXII: 101-112.

Knoppik, C. and T. Beissinger (2003) "How Rigid are Nominal Wages? Evidence and Implications for Germany”, Scandinavian Journal of Economics 105(4): 619-642.

Kohaut, S. and S. Schnabel (2003) „Zur Erosion des Flächentarifvertrages: Ausmaß, Einflussfaktoren und Gegenmaßnahmen“, Industrielle Beziehungen 10 (2): 193-219.

Krueger, D. and K. Kumar (2004), Skill Specific Rather than General Education: A Reason for USEurope Growth Differences? Journal of Economic Growth 9(2): 167-207.

Malcomson, J.M. (1999) “Individual Employment Contracts”, in: Ashenfelter, O. and D. Card, eds., Handbook of Labor Economics, Vol. 3C, Amsterdam: Elsevier, 2291-2372.

Pfeiffer, F. (2003) Lohnrigiditäten im gemischten Lohnbildungssystem, Baden-Baden: Nomos. 
Table I: Results of Previous Surveys

\begin{tabular}{|c|c|c|}
\hline Study & Sample composition & Main Results \\
\hline Kaufman [1984] & $\begin{array}{l}\text { The sample consists of } 26 \text { British firms in Wales, the West Midlands, and the } \\
\text { Greater London area, concentrating on small non-unionized firms. The } \\
\text { median firm size is seven employees, and only six firms have more than } 50 \\
\text { employees. }\end{array}$ & $\begin{array}{l}\text { Firms are asked whether they can find qualified personnel at less } \\
\text { than current wages, and if so, what prevents the firm from cutting } \\
\text { wages. The most common response to the latter question is that } \\
\text { wage reductions would upset workers and that their response would } \\
\text { be a reduction in work effort. }\end{array}$ \\
\hline Blinder and Choi [1990] & $\begin{array}{l}19 \text { large firms in New Jersey and Eastern Pennsylvania are interviewed. } \\
\text { These firms are selected from Ward's Business Directory of U.S. Firms, } \\
\text { which lists companies with annual sales of more than \$11 million. }\end{array}$ & $\begin{array}{l}\text { Strong support is found for theories of wage rigidity, including } \\
\text { fairness and labour turnover. }\end{array}$ \\
\hline $\begin{array}{l}\text { Bewley [1995, 1998, } \\
\text { 1999] }\end{array}$ & $\begin{array}{l}336 \text { interviews with firms (246), temporary labour services (13), headhunters } \\
\text { (15), advisors of the unemployed (26), labour leaders (19), labour lawyers (4) } \\
\text { and management consultants (13) in the Northwest of the United States. } \\
\text { There is much variation between interviews in the topics discussed and in the } \\
\text { questions asked of respondents, so most of the study involves anecdotal } \\
\text { evidence. The sample is obtained by net working, starting with friends, } \\
\text { relatives and calls to local firms. }\end{array}$ & $\begin{array}{l}\text { The most important reason why firms generally do not cut pay } \\
\text { during a recession is that they fear a pay cut would adversely affect } \\
\text { workers' morale and motivation. Respondents indicate that morale } \\
\text { is related more to wage changes and particularly wage decreases } \\
\text { than to wage levels. }\end{array}$ \\
\hline $\begin{array}{l}\text { Agell and Lundborg } \\
{[1995,2003]}\end{array}$ & $\begin{array}{l}179 \text { Swedish manufacturing firms are surveyed first in } 1991 \text {. The survey has } \\
\text { been repeated with the same firms in } 1998 \text { of which } 159 \text { responded; the } \\
\text { sample mainly consists of large firms with an overall unionization rate of } 92 \\
\text { percent. }\end{array}$ & $\begin{array}{l}\text { Workers' concerns about fairness and relative wages play an } \\
\text { important role in explaining why firms do not normally cut wages } \\
\text { in recessions. Despite a considerable rise in unemployment from } \\
1991 \text { to } 1998 \text {, the mechanism generating wage rigidity remain } \\
\text { stable in the Swedish manufacturing firms. }\end{array}$ \\
\hline $\begin{array}{l}\text { Campbell and Kamlani } \\
\text { [1997] }\end{array}$ & $\begin{array}{l}184 \text { US firms, most of them large firms from the Business Week } 1000 \\
\text { corporation, are surveyed. Median employment size is 3,800, its mean } \\
\text { 11,927.1. Three broad categories of labour are introduced: less-skilled, blue- } \\
\text { collar workers, white-collar workers; } 14.7 \text { percent of the firms are unionized. } \\
\text { Some small mid-sized firms are drawn from alumni of Colgate University } \\
\text { (where Campbell was a professor at the time of the survey) and from } \\
\text { personnel networking. }\end{array}$ & $\begin{array}{l}\text { The most important reason for wage rigidity is found for } \\
\text { explanations based on adverse selection in quits and on the effect } \\
\text { of wages on effort. The latter effect is found to be stronger for low- } \\
\text { skilled than for high-skilled workers. Implicit contracts are an } \\
\text { important explanation for wage rigidity for less skilled and blue- } \\
\text { collar workers, while reducing turnover is an important one for } \\
\text { white-collar workers. }\end{array}$ \\
\hline $\begin{array}{l}\text { Agell and Bennmarker } \\
\text { [2002] }\end{array}$ & $\begin{array}{l}\text { The local unit of } 885 \text { representative Swedish firms from four branches } \\
\text { (manufacturing, skilled services, unskilled services and public sector } \\
\text { administration) with more than employees, taken from the Business Register } \\
\text { of Statistics Sweden, are surveyed in } 1999 .\end{array}$ & $\begin{array}{l}\text { Wage rigidity is the result of “exogenous” (primarily labour law } \\
\text { and labour union contracts) and “endogenous” factors (workers' } \\
\text { morale and motivation, money illusion and fairness). These two } \\
\text { mechanisms tend to complement each other and are different } \\
\text { between small and large firms and between branches. }\end{array}$ \\
\hline
\end{tabular}


Table II: Descriptive Statistics

\begin{tabular}{|c|c|c|c|}
\hline Variable (Type of Variables) & Sample mean & Population mean $^{a}$ & Observations $^{b}$ \\
\hline & Percentages & Percentages & \\
\hline \multicolumn{4}{|c|}{ Type of labour union contract $(0,1)$} \\
\hline No labour union contract (reference cat.) & 43.0 & 62.0 & 797 \\
\hline Membership in the employer association & 39.5 & 22.5 & 797 \\
\hline Firm specific labour union contract & 4.1 & 2.1 & 797 \\
\hline Governmental binding union contract wages $^{c}$ & 3.9 & 3.4 & 797 \\
\hline Reference clause in individual contracts & 2.4 & 1.4 & 797 \\
\hline Voluntary application & 7.0 & 8.6 & 797 \\
\hline \multicolumn{4}{|c|}{ Only for firms applying a labour union contract } \\
\hline Are there plants without application?(0 no,1yes) & 12.3 & 12.6 & 454 \\
\hline $\begin{array}{l}\text { Are there pay differences between union and } \\
\text { non-union members? ( } 0 \text { no, } 1 \text { yes) }\end{array}$ & 20.1 & 20.6 & 393 \\
\hline \multicolumn{4}{|c|}{ Skill composition of workers (in percent) } \\
\hline Highly skilled workers & 21.9 & 19.8 & 683 \\
\hline Skilled workers & 60.1 & 67.4 & 683 \\
\hline Less skilled workers & 18.0 & 12.8 & 683 \\
\hline \multicolumn{4}{|c|}{ Industrial composition $(0,1)$} \\
\hline Chemical (reference cat.) & 12.6 & 2.3 & 801 \\
\hline Metal- and engine building, electrical industries & 29.5 & 23.4 & 801 \\
\hline Wholesale and retail trade & 15.9 & 43.2 & 801 \\
\hline Finance and insurance & 11.0 & 1.6 & 801 \\
\hline Firm related services & 27.6 & 25.2 & 801 \\
\hline Others (construction, etc.) & 3.5 & 4.3 & 801 \\
\hline \multicolumn{4}{|c|}{ Number of employees (firm size categories, 0,1 ) } \\
\hline 500+ employees (reference cat.) & 22.4 & 3.1 & 799 \\
\hline $200-499$ & 17.3 & 4.0 & 799 \\
\hline 100-199 & 16.5 & 5.9 & 799 \\
\hline 50- 99 & 15.3 & 11.3 & 799 \\
\hline $20-49$ & 14.0 & 26.7 & 799 \\
\hline $10-19$ & 14.5 & 49.0 & 799 \\
\hline \multicolumn{4}{|c|}{ Location of firms' headquarter $(0,1)$} \\
\hline West Germany (reference cat.) & 73.1 & 73.8 & 789 \\
\hline East Germany & 17.2 & 20.3 & 789 \\
\hline Outside Germany & 9.6 & 5.9 & 789 \\
\hline \multicolumn{4}{|c|}{ There is a workers council in the firm $(0,1)$} \\
\hline Workers’ council & 52.6 & 18.4 & 794 \\
\hline \multicolumn{4}{|c|}{ Evidence of recruitment problems for highly skilled workers $(0,1)$} \\
\hline No evidence (reference cat.) & 58.6 & 69.7 & 753 \\
\hline Evidence & 23.1 & 12.0 & 753 \\
\hline Strong evidence & 18.3 & 18.6 & 753 \\
\hline \multicolumn{4}{|c|}{ Evidence of recruitment problems for skilled workers $(0,1)$} \\
\hline No evidence (reference cat.) & 48.1 & 45.9 & 772 \\
\hline Evidence & 29.9 & 29.6 & 772 \\
\hline Strong evidence & 22.0 & 24.5 & 772 \\
\hline
\end{tabular}

${ }^{a}$ Mean calculated for the population of firms under the assumption of random response.

${ }^{b}$ Number of valid observations for the variable under consideration.

c „Allgemeinverbindlicherklärung“, i.e. all firms in a region and industry have to apply the labour union contracts of that region and industry. 
Table III: Reasons for Wage Rigidity in Germany and the United States

\begin{tabular}{|c|c|c|c|c|c|c|c|}
\hline \multirow[b]{2}{*}{ Statements } & \multirow[b]{2}{*}{ Response category } & \multirow[b]{2}{*}{$\begin{array}{l}\text { 1: Not } \\
\text { important }\end{array}$} & \multirow[b]{2}{*}{$\begin{array}{l}\text { 2: Of minor } \\
\text { importance }\end{array}$} & \multirow[b]{2}{*}{$\begin{array}{l}\text { 3: Moderately } \\
\text { important }\end{array}$} & \multirow[b]{2}{*}{$\begin{array}{l}\text { 4: Very } \\
\text { important }\end{array}$} & \multicolumn{2}{|c|}{ Average scores } \\
\hline & & & & & & $\begin{array}{l}\text { German } \\
\text { population } \\
\left(\text { sample }^{\mathrm{a}}\right)\end{array}$ & $\begin{array}{l}\text { United States } \\
\text { sample }^{b}\end{array}$ \\
\hline & & \multicolumn{6}{|c|}{ Percentages } \\
\hline \multicolumn{8}{|c|}{ a. “Labour union contracts prevent wages from being cut.” } \\
\hline & Highly skilled $^{c}$ & 29.2 & 27.4 & 17.5 & 25.9 & $2.40(2.46)$ & 1.35 \\
\hline & Skilled $^{d}$ & 13.4 & 16.0 & 34.1 & 36.5 & $2.94(3.00)$ & 2.40 \\
\hline & Less skilled $^{e}$ & 12.8 & 13.0 & 17.7 & 56.6 & $3.18(3.30)$ & 2.05 \\
\hline \multicolumn{8}{|c|}{ (sample of firms applying labour union contracts) } \\
\hline & Highly skilled & 27.7 & 28.6 & 13.0 & 30.8 & $2.47(2.54)$ & --- \\
\hline & Skilled & 8.7 & 15.3 & 34.3 & 41.7 & $3.09(3.09)$ & $\begin{array}{ll}-- \\
\end{array}$ \\
\hline & Less skilled & 8.2 & 10.2 & 19.5 & 62.1 & $3.36(3.45)$ & $\begin{array}{ll}-- \\
\end{array}$ \\
\hline \multicolumn{8}{|c|}{$\begin{array}{l}\text { b. "Workers dislike unpredictable changes in income. Therefore, workers and } \\
\text { firms reach an implicit understanding that wages will neither fall in recessions } \\
\text { nor rise in expansions." }\end{array}$} \\
\hline & Highly skilled & 13.6 & 32.4 & 31.7 & 22.2 & $2.63(2.42)$ & 2.59 \\
\hline & Skilled & 6.8 & 20.2 & 47.2 & 25.9 & $2.92(2.71)$ & 2.79 \\
\hline & Less skilled & 13.8 & 16.6 & 32.0 & 37.6 & $2.93(2.86)$ & 2.60 \\
\hline \multicolumn{8}{|c|}{$\begin{array}{l}\text { c. "If your firm were to cut wages, people in the community would hear about it, } \\
\text { making it more difficult to hire workers in the future." }\end{array}$} \\
\hline & Highly skilled & 5.0 & 9.0 & 27.4 & 58.6 & $3.40(3.45)$ & 2.30 \\
\hline & Skilled & 6.6 & 15.4 & 39.1 & 38.9 & $3.10(3.13)$ & 2.36 \\
\hline & Less skilled & 21.5 & 35.1 & 19.8 & 23.7 & $2.46(2.38)$ & 2.20 \\
\hline \multicolumn{8}{|c|}{$\begin{array}{l}\text { d. "A cut in wages would decrease workers' effort, resulting in less output or } \\
\text { poorer service." }\end{array}$} \\
\hline & Highly skilled & 8.8 & 30.6 & 30.7 & 29.9 & $2.82(2.77)$ & 2.77 \\
\hline & Skilled & 5.4 & 25.5 & 42.8 & 26.3 & $2.90(2.84)$ & 2.99 \\
\hline & Less skilled & 10.4 & 25.7 & 34.3 & 29.6 & $2.83(2.70)$ & 2.88 \\
\hline
\end{tabular}


e. "A cut in wages would increase the number of workers who quit, increasing the cost of hiring and training new workers in the future."

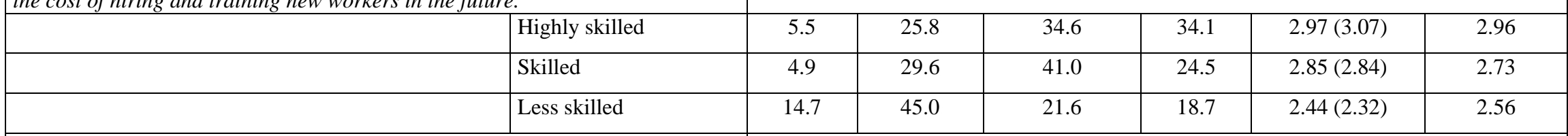

f. "If your firm were to discharge some of its current workers and to hire new workers at a lower wage, the workers who remain would harass and refuse to cooperate with the newly hired workers."

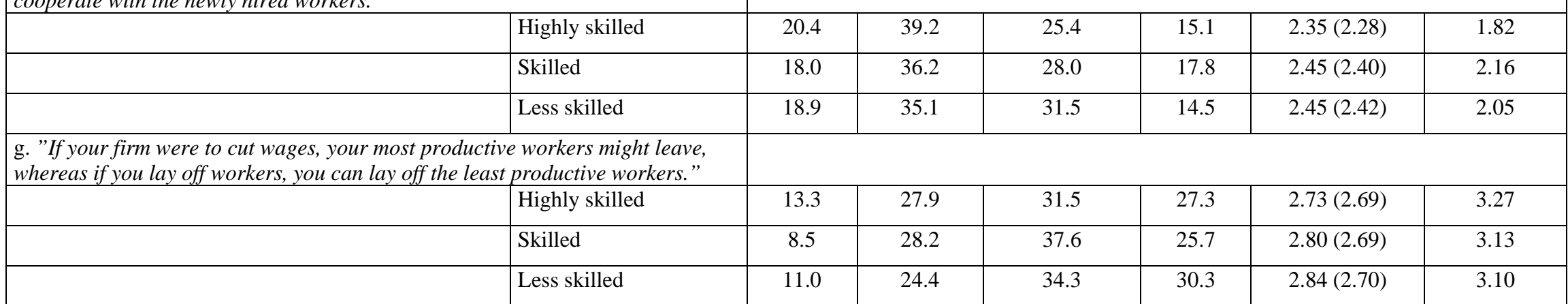

h. "Workers who have been with the firm for a long time have learned how the firm operates and have formed relationships with co-workers and clients. A cut in wages may cause some of your long-time employees to leave, and their replacements would not have this inside knowledge of the firm."

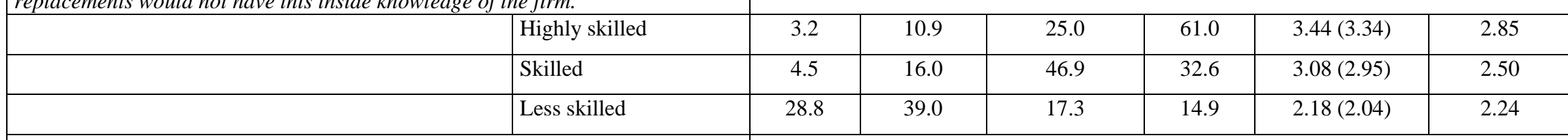

i. "Independent of the effect of wage cuts on profits, people in management positions would be reluctant to cut wages in order to avoid employees' resentment toward them."

\begin{tabular}{|l|l|l|l|l|l|l|l|}
\hline & Highly skilled & 7.4 & 16.7 & 40.5 & 35.4 & $3.04(2.93)$ & 2.52 \\
\hline & Skilled & 5.9 & 15.5 & 41.2 & 37.4 & $3.10(2.94)$ & 2.48 \\
\hline & Less skilled & 7.4 & 12.3 & 45.1 & 35.2 & $3.08(2.86)$ & 2.23 \\
\hline
\end{tabular}

The number of observations with valid information per skill group and question varies between 744 and 792.

${ }^{a}$ Calculations for the population mean of the score are based on the assumption of random response (in brackets sample means for comparison).

${ }^{b}$ From Campbell and Kamlani (1997, table IV). ${ }^{c}$ In Campbell and Kamlani (1997) this category is white-collar; ${ }^{d}$ In Campbell and Kamlani (1997) this category is blue collar; ${ }^{e}$ In Campbell and Kamlani (1997) this category contains workers performing jobs requiring less than 2 years of college. 
Table IV: Pay Moderation and Job Security

\begin{tabular}{|l|c|c|c|c|}
\hline \hline Response category & Yes & No & Not sure & $\begin{array}{c}\text { Number of valid } \\
\text { observations }\end{array}$ \\
\hline \multicolumn{5}{|c|}{ Percentages } \\
\hline \\
„Do you think that the workers in your firm would accept more moderate pay \\
to secure their own working place?“ \\
\hline
\end{tabular}

Calculations for the firm population (calculations for the sample of firms are available on request). 
Table V: Significant Influences on Firms’ Support for Each Explanation on Wage Rigidity

\begin{tabular}{|c|c|c|c|c|c|c|c|c|c|c|c|c|c|c|c|c|c|c|c|c|c|c|c|c|c|c|c|}
\hline \multirow{2}{*}{$\begin{array}{ll} & \text { Statement } \\
\text { Skill group }\end{array}$} & \multicolumn{3}{|c|}{ a. } & \multicolumn{3}{|c|}{ b. } & \multicolumn{3}{|c|}{ C. } & \multicolumn{3}{|c|}{$d$. } & \multicolumn{3}{|c|}{ e. } & \multicolumn{3}{|c|}{$f$. } & \multicolumn{3}{|c|}{$g}$. & \multicolumn{3}{|c|}{ h. } & \multicolumn{3}{|c|}{$i$. } \\
\hline & $H$ & $S$ & $L$ & $H$ & $S$ & $L$ & $H$ & $S$ & $L$ & $H$ & $S$ & $L$ & $H$ & $S$ & $L$ & $H$ & $S$ & $L$ & $H$ & $S$ & $L$ & $H$ & $S$ & $L$ & $H$ & $S$ & $L$ \\
\hline \multicolumn{28}{|c|}{ Legal background for a labour union contract (reference cat.: no labour union contract) } \\
\hline Membership empl.ass. & + & + & + & & & & & & - & & & & & & & & - & & & & & & & & & & \\
\hline Firm specific contract & + & + & + & & & & & & & & - & - & - & & & & & & & & & & & & & & \\
\hline Legally binding & + & + & & & & & & & & & & & & & & & & & & & & & & & & & \\
\hline Reference clause & & & & & & & & & & & & & & & & & & & & & & & & & & & \\
\hline Voluntary application & & & & & & & & & & & & & & & & & & & & & & & & & & & \\
\hline \multicolumn{28}{|c|}{ Industries (reference cat.: chemical) } \\
\hline Metal-, electrical ind. & + & + & + & & & & & & & & & & & & & & & & & + & & & & & & & \\
\hline Trade & & & + & & & & & & & & & & & & & & & & & & & & _ & & & & \\
\hline Finance and insurance & + & + & + & & & & & & & + & + & & & & & & & & + & + & & & _ & _ & & & \\
\hline Firm related services & + & + & + & & & & + & & & & & & & + & & & & & & + & & & & & & & \\
\hline Others (construction, etc.) & & & & & & & & & & & & & & & & & & & & & & & - & & & & \\
\hline \multicolumn{28}{|c|}{ Firm size (reference cat.: 500+) } \\
\hline 10-19 employees & & & & & & & & & & _- & & & + & + & & & & & & & & & & & & & \\
\hline $20-49$ & & + & & & & & & & - & - & & & & & & & & & - & - & - & & & & & & \\
\hline 50- 99 & & & & & & & & & & & & & & & & & & & & & & & & & & & \\
\hline $100-199$ & & & & & & & & & _ & _ & & & & & & & & & & & & & & & & & \\
\hline 200- 499 & & & & & & & & & & 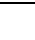 & & & & & & & & & & & & & & & & & \\
\hline \multicolumn{28}{|c|}{ Location of firms' headquarter (reference cat.: West Germany) } \\
\hline East Germany & & & _ & & & & & & & & & _ & & & & & & & & & & & & & & & \\
\hline Outside Germany & & & & & & & & & & & & & & & & 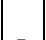 & & & & & & & & & & & \\
\hline \multicolumn{28}{|c|}{ There is a workers' council in the firm (reference cat.: no workers' council) } \\
\hline Workers' council & & & & & & & & & - & & & - & & & & & & & - & - & & & & & & & \\
\hline \multicolumn{28}{|c|}{ Evidence of recruitme } \\
\hline Evidence & 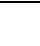 & 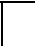 & - & - & & & & & & & & & & & & & & & & & _ & & & & & & \\
\hline Strong evidence & & & & & & & & & & + & + & & & & & & & & + & & _ & & & & & & \\
\hline \multicolumn{28}{|c|}{ Evidence of recruitment problems for skilled (reference cat.: no evidence) } \\
\hline Evidence & & & & & & & & + & & & & & & + & + & & & & & + & + & & & & & & \\
\hline Strong evidence & & & & + & & & + & + & + & & + & + & & + & & & + & + & & + & + & & & & & & \\
\hline Significance $^{a}$ & + & + & + & + & & & + & + & + & + & + & + & + & + & + & & & & & + & & + & + & + & & + & \\
\hline
\end{tabular}

$+/$ - indicates a positive / negative coefficient of one variable was different from zero at the five percent level in an ordered probit model; the number of valid observations in these estimations varies between 689 and 726.

${ }^{a}$ The significance of all explanatory variables in the ordered probit model was tested based on a likelihood ratio test, + indicates that all explanatory variables together are significant at the five percent level. 
Table VI: Correlation Analysis

\begin{tabular}{|c|c|c|c|c|c|c|c|c|}
\hline \multicolumn{9}{|c|}{ Part 1: Correlation between the skill groups for each statement $(\gamma)^{\mathrm{a}}$} \\
\hline a. & \multicolumn{3}{|c|}{0.65} & \multicolumn{2}{|c|}{0.33} & \multicolumn{3}{|c|}{0.88} \\
\hline b. & \multicolumn{3}{|c|}{0.75} & \multicolumn{2}{|c|}{0.23} & \multicolumn{3}{|c|}{0.81} \\
\hline C. & \multicolumn{3}{|c|}{0.72} & \multicolumn{2}{|c|}{0.25} & \multicolumn{3}{|c|}{0.85} \\
\hline d. & \multicolumn{3}{|c|}{0.72} & \multicolumn{2}{|c|}{0.38} & \multicolumn{3}{|c|}{0.93} \\
\hline e. & \multicolumn{3}{|c|}{0.72} & \multicolumn{2}{|c|}{0.37} & \multicolumn{3}{|c|}{0.88} \\
\hline f. & \multicolumn{3}{|c|}{0.83} & \multicolumn{2}{|c|}{0.60} & \multicolumn{3}{|c|}{0.93} \\
\hline g. & \multicolumn{3}{|c|}{0.79} & \multicolumn{2}{|c|}{0.56} & & 0.96 & \\
\hline h. & & 0.70 & & & & & 0.91 & \\
\hline i. & & 0.88 & & & & & 0.96 & \\
\hline Part 2: Co & ion betı & n the stat & ents for e & h skill gr & $(\gamma)^{\mathrm{a}}$ & & & \\
\hline & & & Less & led work & (L) & & & \\
\hline Statement & b. & C. & d. & e. & f. & g. & h. & i. \\
\hline a. & 0.27 & -0.04 & 0.15 & 0.10 & 0.08 & 0.19 & -0.13 & 0.01 \\
\hline b. & --- & 0.12 & 0.23 & 0.16 & 0.13 & 0.06 & 0.19 & 0.13 \\
\hline C. & & --- & 0.47 & 0.53 & 0.10 & 0.26 & 0.50 & 0.22 \\
\hline d. & & & --- & 0.55 & 0.27 & 0.43 & 0.42 & 0.44 \\
\hline e. & & & & --- & 0.20 & 0.29 & 0.48 & 0.20 \\
\hline f. & & & & & --- & 0.38 & 0.22 & 0.10 \\
\hline g. & & & & & & --- & 0.33 & 0.16 \\
\hline h. & & & & & & & --- & 0.24 \\
\hline & & & Ski & dworker & & & & \\
\hline Statement & b. & C. & d. & e. & f. & g. & h. & i. \\
\hline a. & 0.36 & -0.04 & 0.04 & -0.01 & 0.09 & 0.19 & 0.08 & -0.04 \\
\hline b. & --- & -0.01 & 0.13 & 0.14 & 0.07 & 0.19 & 0.16 & 0.28 \\
\hline c. & & --- & 0.58 & 0.54 & 0.14 & 0.19 & 0.38 & 0.32 \\
\hline d. & & & --- & 0.59 & 0.17 & 0.34 & 0.60 & 0.36 \\
\hline e. & & & & --- & -0.01 & 0.39 & 0.56 & 0.31 \\
\hline f. & & & & & --- & 0.30 & 0.32 & 0.21 \\
\hline g. & & & & & & --- & 0.41 & 0.11 \\
\hline h. & & & & & & & --- & 0.37 \\
\hline & & & Highly & illed wor & $s(\mathrm{H})$ & & & \\
\hline Statement & b. & c. & d. & e. & f. & g. & h. & i. \\
\hline a. & 0.27 & 0.04 & 0.12 & -0.13 & 0.12 & 0.10 & -0.04 & 0.04 \\
\hline b. & --- & 0.09 & 0.11 & 0.05 & 0.18 & 0.23 & 0.09 & 0.24 \\
\hline c. & & --- & 0.47 & 0.51 & 0.19 & 0.21 & 0.42 & 0.32 \\
\hline d. & & & --- & 0.51 & 0.18 & 0.33 & 0.45 & 0.24 \\
\hline e. & & & & --- & 0.13 & 0.30 & 0.58 & 0.23 \\
\hline f. & & & & & --- & 0.25 & 0.13 & 0.12 \\
\hline g. & & & & & & --- & 0.36 & 0.16 \\
\hline h. & & & & & & & --- & 0.26 \\
\hline
\end{tabular}

Calculations for the firm population (calculations for the sample of firms are available on request).

${ }^{a} \gamma$ is Goodman's und Kruskal's gamma for ordered variables calculated with STATA6.0; bold type values are significantly different from zero at the 5 percent level. 
Table VII: Pay Differentiation in Labour Union Contracts (Percentages)

i. „Does your labour contract contain the possibility of reducing pay in recessions?”

\begin{tabular}{|c|c|c|}
\hline No & \multicolumn{2}{|c|}{ Yes } \\
\hline 87.6 & \multicolumn{2}{|c|}{12.4} \\
\hline & \multicolumn{2}{|c|}{ „If so: Did your firm take advantage of this } \\
possibility in 1998/99?”
\end{tabular}

Calculations for the population of firms (calculations for the sample of firms are available on request). 
Table VIII: Sample Selection, Stratification and Response

\begin{tabular}{|c|c|c|c|c|c|c|c|}
\hline \multirow{2}{*}{ Industry } & & \multicolumn{6}{|c|}{ Firm size } \\
\hline & & 10-19 & $20-49$ & $50-99$ & $100-199$ & \begin{tabular}{|l|}
$200-499$ \\
\end{tabular} & $500+$ \\
\hline \multirow[t]{3}{*}{ Chemistry } & 1 & 100 & 100 & 100 & 100 & 100 & 100 \\
\hline & 2 & $16.1 \%$ & $16.7 \%$ & $28.0 \%$ & $38.8 \%$ & $47.0 \%$ & $54.4 \%$ \\
\hline & 3 & 11 & 7 & 11 & 22 & 22 & 28 \\
\hline \multirow{3}{*}{$\begin{array}{l}\text { Metal- and engine building, } \\
\text { electrical industries }\end{array}$} & 1 & 200 & 200 & 200 & 200 & 200 & 200 \\
\hline & 2 & $3.1 \%$ & $3.3 \%$ & $7.2 \%$ & $11.5 \%$ & $15.9 \%$ & $25.5 \%$ \\
\hline & 3 & 22 & 40 & 28 & 44 & 50 & 52 \\
\hline \multirow[t]{3}{*}{ Wholesale and retail trade } & 1 & 200 & 200 & 200 & 200 & 200 & 200 \\
\hline & 2 & $0.8 \%$ & $1.3 \%$ & $4.0 \%$ & $8.7 \%$ & $16.0 \%$ & $24.8 \%$ \\
\hline & 3 & 21 & 16 & 28 & 14 & 19 & 29 \\
\hline \multirow[t]{3}{*}{ Finance and insurance } & 1 & 100 & 100 & 100 & 100 & 100 & 100 \\
\hline & 2 & $14.6 \%$ & $21.2 \%$ & $54.0 \%$ & $59.5 \%$ & $59.2 \%$ & $55.3 \%$ \\
\hline & 3 & 10 & 6 & 8 & 10 & 23 & 29 \\
\hline \multirow[t]{3}{*}{ Firm related services } & 1 & 250 & 250 & 250 & 250 & 250 & 250 \\
\hline & 2 & $2.5 \%$ & $3.9 \%$ & $10.2 \%$ & $18.7 \%$ & $24.9 \%$ & $38.2 \%$ \\
\hline & 3 & 47 & 37 & 42 & 41 & 20 & 34 \\
\hline Others $^{a}$ & 3 & 5 & 6 & 5 & 1 & 4 & 7 \\
\hline
\end{tabular}

1 Number of firms randomly selected per cell

2 Percent of firm population selected per cell

3 Respondents

${ }^{a} 28$ respondents from other industries 